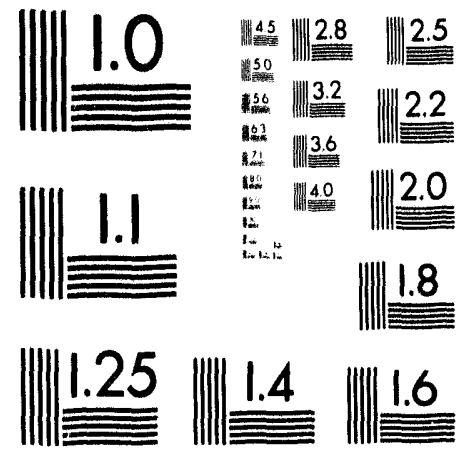



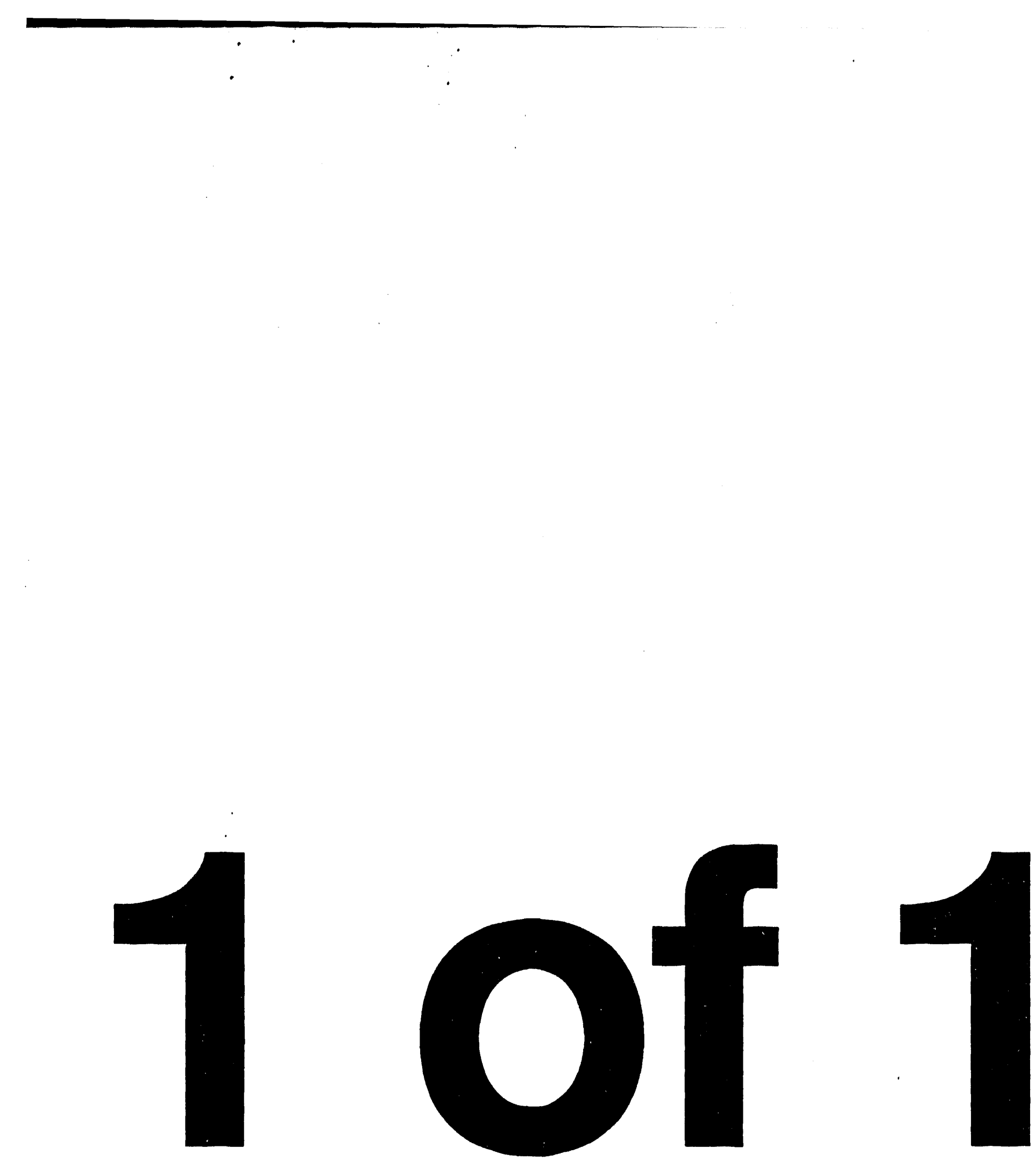
ARGONNE NATIONAL LABORATORY

9700 South Cass Avenue, Argonne, Illinois 60439

\section{Preliminary Assessment Report for National Guard Facility, Installation 25255, Rehoboth, Massachusetts}

\section{Prepared for}

National Guard Bureau, Army Directorate

Aberdeen, Maryland

August 1993

Prepared by

Applied Geosciences and Environmental Management Section

Environmental Research Division

Argonne National Laboratory

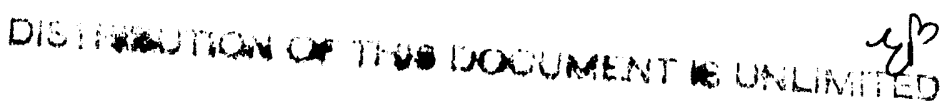




\section{\begin{tabular}{|l|l}
\hline REPORT DOCUMENTATION PAGE & FORM APPROVED
\end{tabular} OMB No. 0704-0188}

Public reporting burden for this collection of information is estimated to average 1 hour per response, including the time for reviewing instructions, searching existing data sources, gathering and maintaining the data needed, and completing and reviewing the collection of information. Send comments regarding this burden estimate or any other aspect of this collection of information, including suggestions for reducing this burden to Washington Headquarters Services, Directorate for Information Operations and Reports, 1215 Jefferson Davis Highway, Suite 1204, Arlington, VA 22202-4302 and to the Office of Management and Budget, Paperwork Reduction Project (0704-01880), Washington, DC 20503.

\begin{tabular}{||c|c|c|}
\hline $\begin{array}{l}\text { 1. AGENCY USE ONLY } \\
\text { (Leave Blank) }\end{array}$ & $\begin{array}{c}\text { 2. REPORT DATE } \\
\text { August 1993 }\end{array}$ & $\begin{array}{l}\text { 3. REPORT TYPE AND DATES COVERED } \\
\text { Preliminary site visit to complete assessment. }\end{array}$ \\
\hline
\end{tabular}

4. TITLE AND SUBTITLE

Preliminary Assessment Report for National Guard Facility,

5. FUNDING NUMBERS

Installation 25255, Rehoboth. Massachusetts

6. $\operatorname{AUTHOR}(S)$

MIPR-3788

MIPR-4188

Rebecca Haffenden; Sam Flaim; Michael Krokosz

7. PERFORMING ORGANIZATION NAME(S) AND ADDRESS(ES)

Candace M. Rose

Argonne National Laboratory

9700 South Cass Avenue

Argonne, IL 60439

9. SPONSORING/MONITORING AGENCY NAME(S) AND ADDRESS(ES)

National Guard Bureau

Army Directorate

Aberdeen, MD 21010-5420

8. PERFORMING

ORGANIZATION

REPORT NUMBER

None

10. SPONSORING/

MONITORING AGENCY

REPORT NUMBER

IR-CR-93078

11. SUPPLEMENTARY NOTES

None.

12b. DISTRIBUTION

CODE

\section{ABSTRACT (MAXIMUM 200 WORDS)}

This report addresses the information necessary to complete the PA.

14. SUBJECT TERMS

15. NUMBER OF PAGES

PA-48

16. PRICE CODE

17. SECURITY REPORT CLASSIFICATION OF

18. SECURITY CLASSIFICATION OF THIS REPORT

Unclassified
Unclassified
19. SECURITY

CLASSIFICATION OF ABSTRACT

Unclassified
20. LIMITATION OF

ABSTRACT

Unlimited 


\section{Contents}

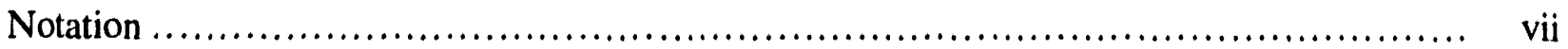

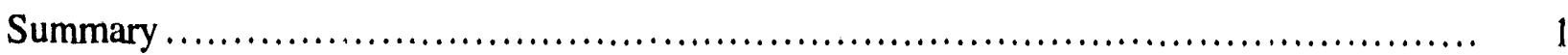

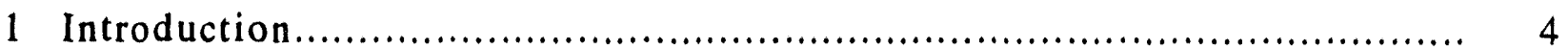

1.1 Authority for the Preliminary Assessment ................................... 4

1.2 Objectives ......................................................................... 4

1.3 Procedures ....................................................................................... 5

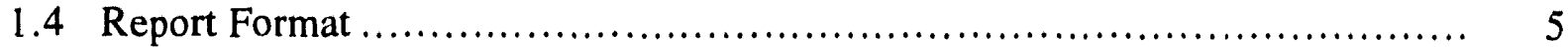

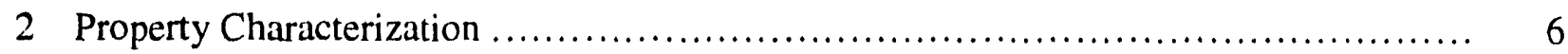

2.1 General Property Information..................................................... 6

2.2 Description of Facilities.......................................................... 6

2.2.1 Operational Maintenance Shop (Building C-9) ...................... 9

2.2 .2 Vehicle Washracks ................................................... 9

2.2.3 Lube and Oil Shed (Building C-10) ................................... 11

2.2.4 Vehicle Parking and Fuel Dispensing Island.............................. 11

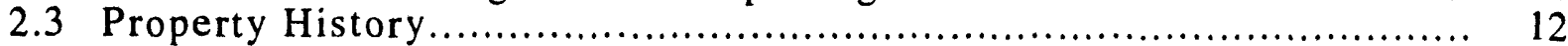

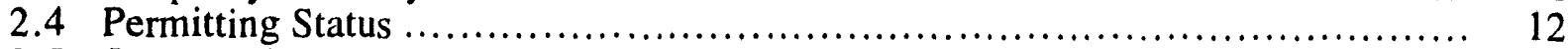

2.5 Surrounding Environment and Land Use .............................................. 13

2.5.1 Demographics and Land Use....................................... 13

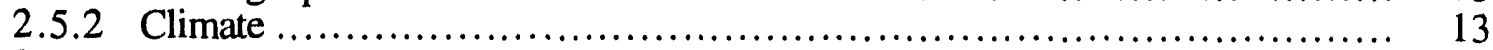

2.5.3 Surface Water and Physiography ................................... 14

2.5.4 Groundwater and Hydrogeology .............................................. 16

2.5.5 Sensitive Environments............................................... 22

3 Environmentally Significant Operations ............................................ 23

3.1 Vehicle Fuel Dispensing Station, Vehicle Operator Maintenance, and Vehicle Washracks ............................................................... 23

3.2 Filling Underground Heating Oil Tanks................................................ 25

3.3 Abandoned Underground Storage Tanks and Wells ............................. 25

4 Known and Suspected Releases ................................................. 27

4.1 Releases to Groundwater ................................................... 27

4.2 Releases to Surface Water ............................................................... 27

4.3 Releases to Soil ................................................................ 27

4.4 Releases to Air ......................................................................... 28

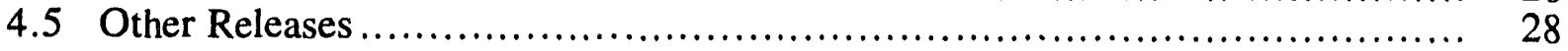

5 Human and Environmental Receptors................................................... 29

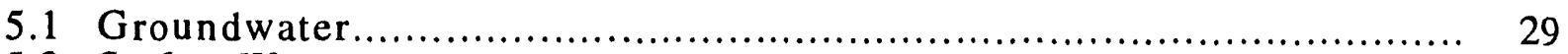

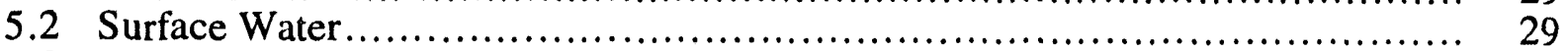

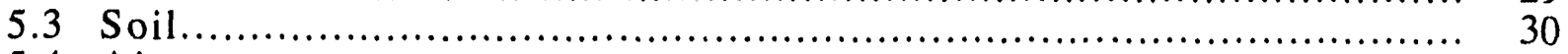

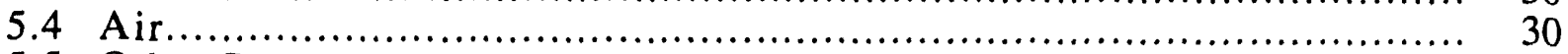

5.5 Other Receptors......................................................................... 30 


\section{Contents (Cont.)}

6 Preliminary Assessment Findings and Conclusions ............................ 31

6.1 Summary of Preliminary Assessment Findings .............................. 31

6.2 Recommendations for Further Action ..................................... 31

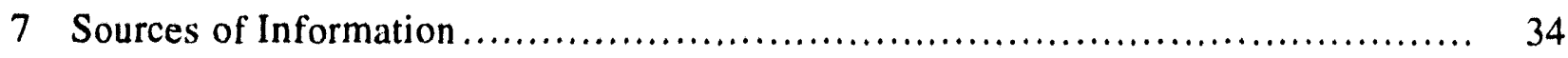

7.1 References ...................................................................... 34

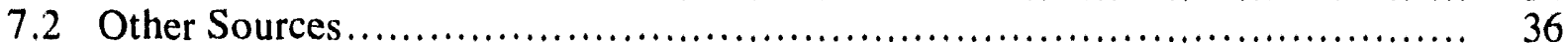

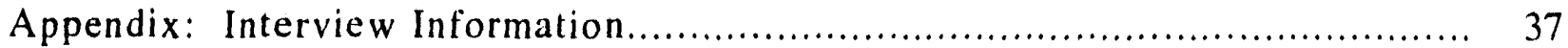

Table

1 Identifying Information for the RNGF, Rehoboth, Massachusetts ................. 8

Figures

1 General Location of the RNGF ................................................. 7

2 Site Plan of the RNGF ........................................................... 10

3 Surface Water...................................................................... 15

4 Generalized Geologic Sketch Map and Basic Stratigraphy of the Narragansett Basin ............................................................................ 18

5 Drinking Water Well Areas......................................................... 20

6 Locations of ESOs at the RNGF ............................................... 24 


\section{Notation}

\section{Acronyms}

$\begin{array}{ll}\text { ACQR } & \text { acquisition ratio } \\ \text { ARNG } & \text { Army National Guard } \\ \text { CERCLA } & \text { Comprehensive Environmental Response, Compensation, and Liability Act } \\ \text { EPA } & \text { U.S. Environmental Protection Agency } \\ \text { ESO } & \text { environmentally significant operation } \\ \text { IRP } & \text { Installation Restoration Program } \\ \text { MAARNG } & \text { Massachusetts Army National Guard } \\ \text { MCL } & \text { maximum contaminant level } \\ \text { MTR } & \text { missile-tracking radar } \\ \text { MSL } & \text { mean sea level } \\ \text { NPDES } & \text { National Pollutant Discharge Elimination System } \\ \text { NSDWR } & \text { National Secondary Drinking Water Regulations } \\ \text { OMS } & \text { operational maintenance shop } \\ \text { PA } & \text { preliminary assessment } \\ \text { RNGF } & \text { Rehoboth National Guard Facility } \\ \text { TTR } & \text { target-tracking radar } \\ \text { USAEHA } & \text { U.S. Army Environmental Hygiene Agency } \\ \text { USGS } & \text { U.S. Geological Survey }\end{array}$

\section{Units of Measure}

$\begin{array}{ll}\mathrm{d} & \text { day } \\ \mathrm{ft} & \text { foot } \\ \mathrm{gal} & \text { gallon } \\ \mathrm{h} & \text { hour } \\ \text { in. } & \text { inch } \\ \mathrm{mi} & \text { mile } \\ \text { min } & \text { minute } \\ \text { psi } & \text { pounds per square inch }\end{array}$




\section{Preliminary Assessment Report for National Guard Facility, Installation 25255, Rehoboth, Massachusetts}

\section{Summary}

This report presents the results of the preliminary assessment (PA) conducted by Argonne National Laboratory at the Massachusetts Army National Guard (MAARNG) property known as the Rehoboth National Guard Facility (RNGF) in Rehoboth, Massachusetts. Preliminary assessments of federal facilities are being conducted to compile the information necessary for completing preremedial activities and to provide a basis for establishing corrective actions in response to releases of hazardous substances. The principal objective of the PA is to characterize the site accurately and determine the need for further action by examining site activilies, quantities of hazardous substances present, and potential pathways by which contamination could affect public health and the environment. This PA satisfies, for the RNGF property, phase I of the Department of Defense Installation Restoration Program (IRP). The scope of this assessment is limited to the facilities under the control of the MAARNG and the past activities contained within that area.

The RNGF is a 15-acre site located in the southeastern portion of Massachusetts, approximately $3 \mathrm{mi}$ northeast of Rehoboth, Massachusetts, in the county of Bristol. The facility was a Nike missile battery control area (or integrated fire control area) from 1958 until 1974 and has been a National Guard facility since approximately 1977. The site houses the Headquarters Headquarters Battalion, 26th Division Artillery (supply and offices in Building C-13), Battalion E Tab (supply sergeant and administrative officer in Building C-2), and A Company, 126th Signal Battalion (Building $\mathrm{C}-12$ ). The site is used as the motor pool, parking facilities, and fuel dispensing station for National Guard units drilling in Cape Cod, Massachusetts. The environmentally significant operations associated with the property are (1) a vehicle fuel dispensing station, vehicle operator maintenance, and the vehicle washracks; (2) filling underground heating oil tanks; and (3) abandoned underground storage tanks and wells.

The review of both historical and current practices at the property indicated that the RNGF property poses a low level of risk to human health or the environment. Although they are not 
necessarily waste sources under the IRP guidelines, Argonne's reviewers noted the following areas of concern, which could result in the release of contaminants to the environment:

- On the west side of the leach field, two to three garbage cans have been burned to ash on the soil, leaving a gummy, white-silver ash (possibly film destruction) that will leach into the soil.

- Although the abandoned sewage treatment plant has been removed, no sampling of the soil was done after removal and before refilling and grading, so whether any contamination is present at this location is unknown.

- A small cap, which is located about $8 \mathrm{ft}$ from the current pump and well, covers a very deep hole that contains liquid, possibly an old abandoned well that has not been closed completely.

- An abandoned 2,000-gal fuel oil underground storage tank, still containing product, is located next to the generator building (Building $C-5$ ) on the hill.

- All five active underground storage tanks containing heating oil have stained areas around the fill pipes. Some pipes are situated to allow any spillage to run off into the storm-water collection system, but in other cases, runoff is into the soil.

- A small 1-in.-diameter pipe runs out of the wall behind Building C-9; the pipe is very rusted, and its origin could not be ascertained because no one had a key for the building; this pipe should be investigated for possible past use as a battery-acid treatment outfall.

- The temporarily capped standpipe of another abandoned underground storage tank, containing an unknown liquid, was located to the north of Building C-9.

- Stains are visible on the diesel fuel dispensing island, and the dispensing area has only a makeshift spill containment consisting of plastic sheeting and sandbags. 
- Located west of the interconnecting building (Building C-6) is a dry well, which may have been used for disposal of wastes during the years when the site was a Nike battery control area. 


\section{Introduction}

This document is a report of the preliminary assessment (PA) conducted by Argonne National Laboratory at the Massachusetts Army National Guard (MAARNG) property known as the Rehoboth National Guard Facility (RNGF), located in Rehoboth, Massachusetts.

\subsection{Authority for the Preliminary Assessment}

The National Guard Bureau, Army Directorate, has engaged Argonne to perform PAs of selected state Army National Guard (ARNG) properties. These assessments are being done in a manner consistent with both the Department of Defense Installation Restoration Program (IRP) and the U.S. Environmental Protection Agency's (EPA's) Potential Hazardous Waste Site Preliminary Assessment Guidance. Preliminary assessments of state ARNG properties are conducted under the authority and direction of the IRP; the Comprehensive Environmental Response, Compensation, and Liability Act (CERCLA or, more commonly, Superfund); and the Superfund Amendments and Reauthorization Act of 1986 (P.L. 99-499).

\subsection{Objectives}

This PA report is based on existing information from the MAARNG records that were made available to Argonne investigators and from other sources. Although this PA effort did not extend to the generition of new data, it nonetheless identifies areas where existing data are incomplete, unreliable, or ambiguous and recommends ways to address such shortcomings.

The objectives of the PA are to satisfy phase I of the IRP and to

- Identify and characterize the environmentally significant operations (ESOs),

- Identify property areas or ESOs that may require a site investigation,

- Identify ESOs or areas of environmental contamination that may require immediate removal, 
- Identify properties for which no further action is needed, and

- Provide information sufficient to prescore the site with the EPA's PA Scoresheets (September 1991).

\subsection{Procedures}

The PA began with a review of MAARNG files located at MAARNG Headquarters at Camp Curtis Guild, Reading, Massachusetts, on April 19, 1993. A site visit was conducter, on April 22, 1993, to obtain additional information through direct observation and interviews with personnel familiar with the property and its operations. In addition, interviews with personnel from the Rehobuth Board of Health; the town clerk, Assessor's Office, and Water Department of Attleboro; the Planning Department, Assessor's Office, and Water Department of Norton; the Assessor's Office, town clerk, Water Department, and Board of Health of Taunton; and the Assessor's Office and Board of Health of Dighton, Massachusetts, were conducted on April 22, 1993. Other relevant information was obtained on April 23, 1993, in the Boston, Massachusetts, offices of the Massachusetts Department of Environmental Management, Office of Water Resources, the Massachusetts Division of Fisheries and Wildlife, and the Massachusetts Department of Environmental Protection, Office of Planning and Program Management, Division of Water Supply. In addition, telephone interviews were conducted with the water and health departments and city clerks of Rehototh, Attleboro, Norton, Taunton, and Dighton.

\subsection{Report Format}

This PA report presents a summary and evaluation of the data relevant to the PA for this property. Section 2 describes the property and its surrounding environment and land use. Section 3 identifies and characterizes the ESOs at the site. Section 4 discusses known and suspected releases to the environment, and Section 5 discusses potential human and environmental receptors for such releases. Section 6 summarizes the findings and conclusions, discusses the quality and reliability of the supporting information, identifies areas requiring further action, and suggests how' such actions can be accomplished. Section 7 lists pertinent materials reviewed. The Appendix contains interview information and lists the Argonne investigators. 


\section{Property Characterization}

\subsection{General Property Information}

The property studied is a compound of approximately 15 acres located in Rehoboth. Massachusetts. The site is located in a residential area. The RNGF was previously the battery control area (or integrated fire control area) for a Nike missile site. The accompanying launcher site, located some miles away, was transferred to the town of Rehoboth and is not a part of this PA. Currently, the RNGF is used to park MAARNG vehicles and dispense fuel for MAARNG units drilling at Cape Cod, Massachusetts. The facility once served as an orgunizational maintenance shop; however, no vehicle maintenance, other than operator maintenance (i.e.. inspection of fluid levels, adding oil or coolant, etc.), is currently perfnemed at the site, according: to a motor sergeant at the RNGF.

The site houses the Headquarters Headquarters Battalion. 26th Division Artillery (supply and offices in Building C-13), Battalion E Tab (supply sergeant and administrative officer in Building C-2), and A Company, 126th Signal Battalion (Building C-12). The site is occupied by 34 people for eight hours per day, five days per week in the office areas in Buildings C-13, C.2. and C-12 (USAEHA 1987). The motor pool is closed during the week and only open on weekends. On most weekends, 20 to 25 people use the facility; however, for five weekends per year, 250 to 270 people come for National Guard exercise activities (information from motor sergeant, RNGF). A map showing the general location for the RNGF is provided in Figure I, and Table 1 lists pertinent information about the property.

\subsection{Description of Facillties}

Most of the buildings at the RNGF are barracks and administration buildings, which have no ESOs. Buildings $\mathrm{C}-13, \mathrm{C}-2$, and $\mathrm{C}-12$ are office or supply buildings. Building $\mathrm{C}-3$ is the mess hall, and Building $\mathrm{C}-1$ is the barracks. The RNGF is now used as a MAARNG motor pool and has a large military vehicle parking area with a ulesel fuel dispensing island (supplied from a 5,000-gal underground storage tank) and two vehicle washracks. The site also has three storage buildings (Building C-8, Building C-11 [flammables], and Building C-10 (lube oil shed)), the operational maintenance shop (OMS 21A) (Building C-9), and a pump house (Building C-4). 


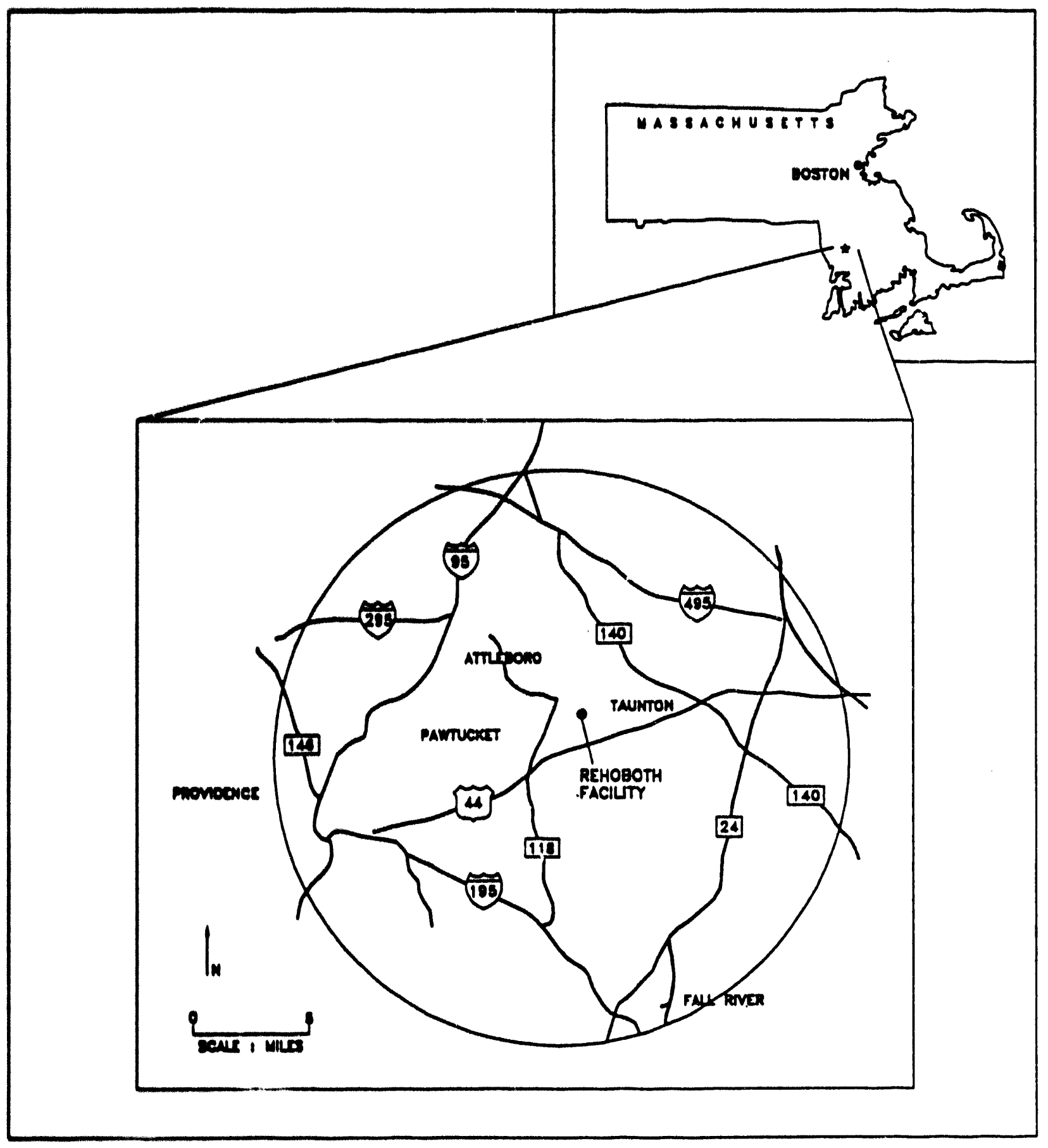

FICURE 1 General L.ocation of the RNGF (Sources: USGS 1979, 1985, 1987a,b) 
TABLE 1 Identifying Information for the RNGF, Rehoboth, Massachusetts

\begin{tabular}{|c|c|}
\hline Installation address & $\begin{array}{l}\text { National Guard Facility } \\
\text { Fairview Avenue } \\
\text { Rehoboth, MA } 02769\end{array}$ \\
\hline $\begin{array}{l}\text { Geographic location } \\
\text { Latitude } \\
\text { Longitude } \\
\text { County } \\
\text { Township }\end{array}$ & $\begin{array}{l}41^{\circ} 51^{\prime} 00^{\prime \prime} \mathrm{N} \\
71^{\circ} 15^{\prime} 00^{\prime \prime} \mathrm{W} \\
\text { Bristol } \\
\text { Rehoboth }\end{array}$ \\
\hline FISPa installation number & 25255 \\
\hline Commander & Col Leite \\
\hline Type of facility & Armory \\
\hline License information & $\begin{array}{l}\text { License DACA33-3-87-28, dated February } 18,1987 \text {, } \\
\text { for an indefinite period }\end{array}$ \\
\hline Principal contact & $\begin{array}{l}\text { State Environmental Manager } \\
\text { MAARNG Headquarters } \\
\text { Camp Curtis Guild } \\
25 \text { Haverhill Street } \\
\text { Reading, Massachusetts } \\
\text { (617) 944-0500 × } 2525\end{array}$ \\
\hline
\end{tabular}

a Facility Inventory and Stationing Plan.

The RNGF was once a Nike missile battery control area (Nike 19), and at the top of the hill are three aligned concrete pads that once held radar and communication equipment, an engine generator and frequency changer building (Building C-5), and an interconnecting corridor building (Building C-6) that connects two concrete areas and an electrical substation. These buildings and pads are now abandoned.

The site has two drinking water wells with pumps. Well No. 2 has not been operational since 1987 (USAEHA 1987). No treatment of the well water is provided. A chlorine solution tank and metering pump were installed in the pump house but have not been operated. The water is stored in a 24,000-gal ground-level standpipe tank and pumped into the distribution system using a 4,000-gal pressure tank. 
A septic system at the site consists of a septic tank with pumps and a distribution box running to a leach field lying to the southeast of Building C-13. An abandoned activated sludge treatment tank has been removed. The two steel tanks (aeration), a siphon chamber, some structural steel, old pumps, and associated piping and valves were removed in 1987 . The contractor, G.M. Berkley Corp., North Falmouth, Massachusetts, removed the 64,200 gal of sewage to an approved off-site location and removed the steel sewage plant with sprayer apparatus and in-ground concrete separator and equipment. The tanks were removed and the area backfilled and graded. No documentation exists of soil sampling prior to such backfilling.

The buildings at the RNGF are heated by fuel oil-fired boilers. Five active 2,000-gal underground storage tanks contain No. 2 fuel oil for the boilers serving Buildings C-1, C-2, C-3, C-12, and C-13. The fill pipes are set approximately $12 \mathrm{in}$. out of the ground. The fill pipes are surrounded by visible stains in the gravel and dirt.

The locations of these facilities are shown in Figure 2. Specific facilities are described subsequently.

\subsubsection{Operational Maintenance Shop (Building C-9)}

Currently, no vehicle maintenance is performed at the RNGF. Only operator maintenance is done, which includes adding coolant or oil and checking and replacing batteries without draining. All work on vehicles requiring the changing of oil, disposing of batteries, and servicing of air-conditioning, transmission, or coolant systems is performed at the Fall River maintenance area. In the past, this building was used for vehicle maintenance. A small 1-in.-diameter pipe runs out of the wall behind Building C-9 and empties directly to the ground; the pipe is very rusted. The origin of the pipe could not be ascertained because no key was available for the building. This

pipe should be investigated for possible past use as a battery-acid treatment outfall and as a possible source for contamination of the soil.

\subsubsection{Vehicle Washracks}

A National Pollutant Discharge Elimination System (NPDES) application to discharge wastewater was submitted on March 11, 1986; however, no action has yet been taken by the EPA, 


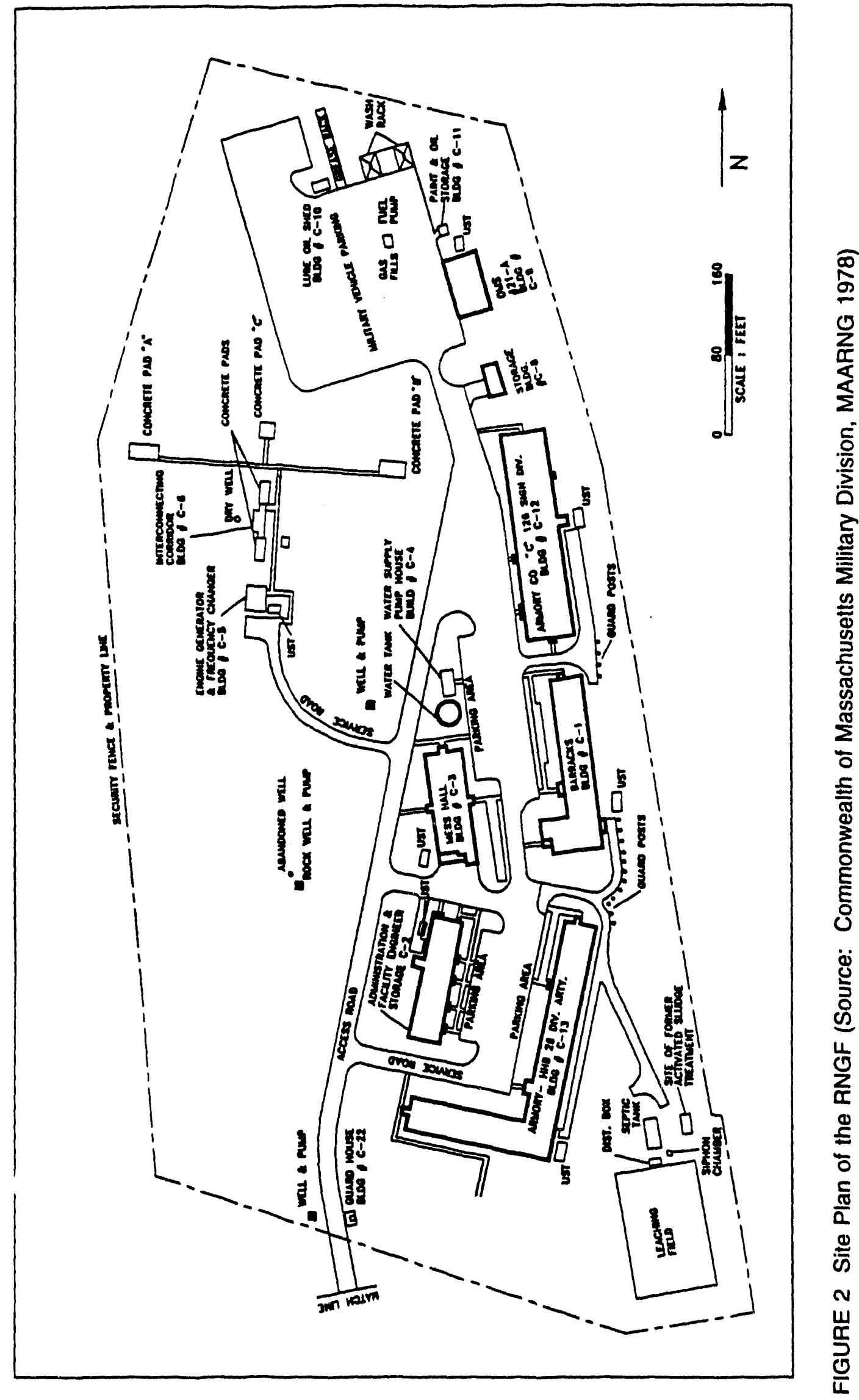


Region I. That application states that the washracks are used only for hosing down vehicles returning from field exercises and that no soaps or detergents are used during this activity. The application states that this water enters the storm drain and discharges to outfall 001 . No drawings indicate the location of the outfall, but it appears to discharge to the northeast of the site. Oil/water separators are located in each of the washracks. The oil/water separators had not been cleaned recently; however, they are part of a statewide cleaning contract currently under bid, according to the Environment Project Manager (MAARNG Headquarters).

\subsubsection{Lube and Oil Shed (Building C-10)}

This small building is used to store paints and other hazardous materials. The storage is in disarray, and the building is in poor condition. The opportunity exists for a spill inside the building to enter the environment; however, no stains or distressed vegetation was observed.

\subsubsection{Vehicle Parking and Fuel Dispensing Island}

The paved parking area is approximately $260 \mathrm{ft} \times 180 \mathrm{ft}$ and paved with asphalt. Vehicles are parked over the washracks and on the grass. The asphalt is cracked. No signs were found of large stains or distressed vegetation. At the far north edge of the paved parking area is the remainder of long ramps that appear to be for the maintenance of trailers or large, long vehicles. No signs of maintenance waste or stains exist. The paved area slopes to the northeast, and storm-water drainage, as well as spills from the diesel fueling island or leaks from trucks, would run toward the vehicle washracks or the abutting soil at the northeastern point.

The diesel fuel for the dispensing island is stored in a 5,000-gal underground storage tank. Notification of installation of the tank was submitted to the local fire department in November 1987. The tank is of steel construction with internal protection (cathodic protection) and interior lining (epoxy resins), with exterior cathodic protection. The piping is galvanized steel. The tank was tested for tightness by PetroTite Corp. on November 19, 1987. The report of those tests indicates that the tank was installed and covered with earth; the fills are 4 in., and there are no siphons and no pumps. The water table was below the tank, and no water was over the tank. The test report indicates that the tank is tight pursuant to the National Fire Protection Association Pamphlet 329. Leakage was indicated at $-0.020 \mathrm{gal} / \mathrm{h}$. 
The tank was tested again on June 18, 1991. The results indicate that the test was performed in a standpipe at the level of $156 \mathrm{in.}$ above the tank bottom to maintain minimum pressure of 2 psi on the tank bottom compensating for groundwater above the tank bottom. The test indicated product loss of $0.00792 \mathrm{gal} / \mathrm{h}$, which is below the Massachusetts requirements of $0.05 \mathrm{gal} / \mathrm{h}$ (as set forth in $310 \mathrm{CMR} 4$ and $527 \mathrm{CMR}$ 9). The data chart for this test shows groundwater 38 in. above the bottom of the tank.

To prevent runoff from spills during the refueling of vehicles, a makeshift containment area was constructed of plastic sheeting and sandbags. Stains are found around the base of the dispensing pump, apparently from filling portable gas cans. No visible signs of a significant release of fuel were present.

\subsection{Property History}

Between 1958 and 1974, this site was a Nike missile battery control center (Nike 19). The battery control area at a Nike site contained all of the radar, guidance, electronic, and communications equipment needed to identify incoming targets, launch missiles, and direct missiles in flight. This equipment included a computer used to determine an intercept point and to guide the missile to that point. The acquisition radar (ACQR), target-tracking radar (TTR), and missile-tracking radar (MTR) were housed in mobile trailers and interconnected with communication cables.

Historically, the areas of possible environmental contamination at a battery control center would be from motor pool activities; septic systems; diesel, fuel oil, and gasoline storage tanks; and unofficial dumping of wastes on-site. Normally, only organizational maintenance of vehicles (oil changes, tune-ups, and minor repair) was conducted at the battery site. Primary wastes generated from maintenance of support equipment were battery acid, waste oil, brake fluid, and transmission fluids and spent solvents (McMaster et al. 1984; Law Engineering Testing Co. 1986).

\subsection{Permitting Stativo}

The MAARNG holds a hazardous-waste small-quantity generator identification number (MAD981071640) from the Massachusetts Department of Environmental Quality. Although current activities do not generate hazardous wastes, unapproved activities in the past at the motor pool generated vehicle maintenance wastes, and, therefore, the small-quantity generator 
identification number was obtained, according to the State Environmental Manager (MAARNG Headquarters).

The MAARNG submitted a NPDES wastewater discharge application on March 11, 1986, for this facility; however, no action has been taken by the EPA, Region I. The MAARNG holds no air emission permits; however, a permit for open burning is required.

\subsection{Surrounding Environment and Land Use}

\subsubsection{Demographics and Land Use}

The area surrounding the RNGF is residential. Some limited small nursery industries exist. The towns of Attleboro (population: 34,910), Norton (population: 13,710), Taunton (population: 45,760), Dighton (population: 5,420), and Rehoboth (population: 8,490) lie within a 4-mi radius of RNGF. The RNGF has approximately 34 people working eight hours per day, five days per week. One weekend per month, approximately 20 to 25 people assemble at the site for training. On five weekends per year, 250 to 270 people come for MAARNG exercise activities, according to a motor sergeant at the RNGF.

\subsubsection{Climate}

The RNGF lies 10 mi northeast of Providence, Rhode Island, and the coast of Narragansett Bay. Narragansett Bay and the Atlantic Ocean play an important part in determining the climate for Providence and vicinity. In winter the temperatures are modified considerably, and many major snowstorms change to rain before reaching the area. In summer, many days that could be uncomfortably warm are cooled by sea breezes. In early fall, severe coastal storms of tropical origin sometimes bring destructive winds to this area. Even at other times of the year, coastal storms usually produce the severest weather. As measured between 1951 and 1980 at the weather station in Taunton, Massachusetts, the average temperature for January was $27.0^{\circ} \mathrm{F}$ and for July was $71.3^{\circ} \mathrm{F}$, with a mean annual temperature of $48.9^{\circ} \mathrm{F}$ (Ruffner 1985; Bair 1992). Average annual precipitation is $45.77 \mathrm{in}$. Thunderstorms are responsible for much of the rainfall from May through August. The month of greatest snowfall is usually February, although most of the winter precipitation is in the form of rain or wet snow. Winds are usually northwesterly during the winter months and southwesterly during the sumıner months, with an annual mean speed of $10.6 \mathrm{mi} / \mathrm{h}$. 


\subsubsection{Surface Water and Physiography}

Rehoboth is located entirely within the Seaboard Lowlands of the New England physiographic province (Harrison et al. 1983) and displays low relief. The general topography of this area is flat to gently rolling, interspersed with low, hummocky, elongate knolls with distinctive north-south trends that decrease in elevation southward. The hummocks are separated by semicontinuous marshes. Surface water bodies, wetlands, and marshes are shown on Figure 3.

Elevations in the area range from $25 \mathrm{ft}$ to $270 \mathrm{ft}$ above mean sea level (MSL). Low-lying areas with elevations of less than 1-2 ft occur as marshes and wetlands between the low hummocky knolls (Willey et al. 1978). Approximately $80 \mathrm{mi}^{2}$ of the area surrounding RNGF is characterized on the U.S. Geological Survey (USGS) quadrangle maps of Somerset, Taunton, and Attleboro, Massachusetts, and of East Providence, Rhode Island, as submerged marsh, marsh, or swamp. Elevations at the RNGF range from $214 \mathrm{ft}$ to $264 \mathrm{ft}$ above MSL.

The highest elevations correspond with the three concrete pads, the generator building (C-5), and the interconnecting building (C-6). Surface runoff from these areas forms a radial drainage pattern that initially intercepts Rehoboth State Forest to the west, the firebreak to the northwest, the military vehicle parking to the north, and the access road to the east. Abutting the perennial East Branch of the Palmer River and approximately $700 \mathrm{ft}$ east of Buildings C-5 and C-6 is the boundary for a 13-acre portion of the Rehoboth State Forest. During periods of high runoff, surface water from the west side of the site discharges either to or adjacent to portions of the Rehoboth State Forest and surrounding Great Meadows Swamp.

Elevations of the remaining area, the eastern half of the site, range from $247 \mathrm{ft}$ to $253 \mathrm{ft}$ above MSL. Surface drainage from these areas flows onto the access road and then south to Fairview Avenue, northwest to the East Branch of the Palmer River and the Great Meadows Swamp, or eastward toward Francis Street. Francis Street is a north-south improved-surface light-duty road that connects Peck Street to the north and Fairview Avenue to the south. The central portion of the road maintains a topographic and surface-water low position immediately east of the RNGF. This street would direct the runoff from the RNGF to the Great Meadow Hiil and to Squannakonk Swamp and, eventually, to Bad Luck Swamp lying south of the site.

The surface runoff from the military vehicle parking area and other northern portions of the RNGF discharges to a separate 123-acre portion of Rehoboth State Forest lying to the north of the 


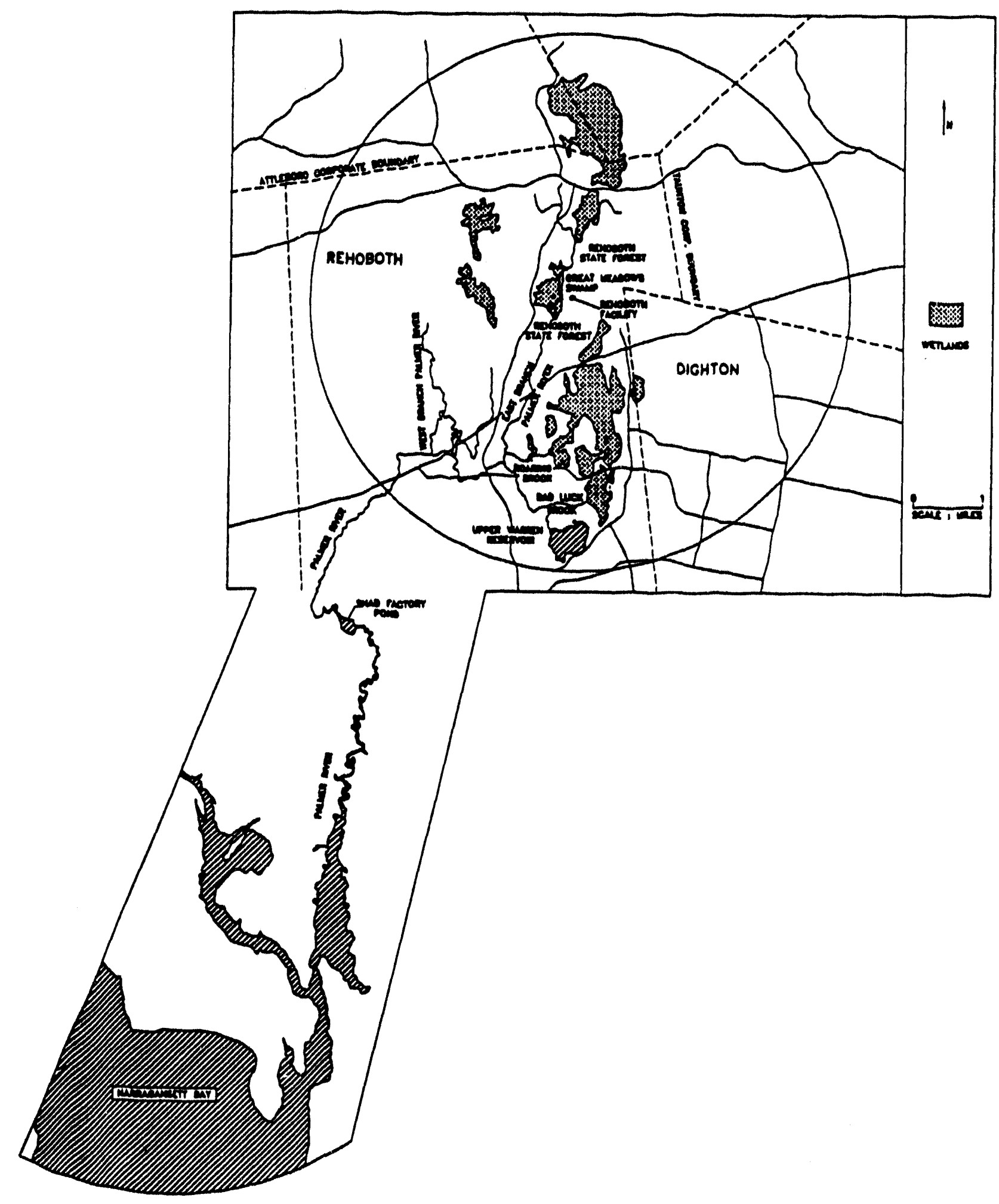

FIGURE 3 Surface Water (Sources: USGS 1979, 1985, 1987a,b) 
site and to the East Branch of the Palmer River. The eastern portion of the parking area drains to the northeast corner of the parking area and into the vehicle washracks, thereby to Francis Street.

Upon intercepting the area surrounding the RNGF, runoff is gravity-fed into the marshlands. Water runoff to the west and north then migrates by overland flow to both portions of Rehoboth State Forest and the East Branch of the Palmer River; runoff to the east intersects Francis Street and the access road and travels along this topographic and surface-water low position to the Squannakonk Swamp, and, eventually, to Bad Luck Swamp to the south. Bad Luck Swamp forms the watershed for the Upper Warren (Anawan) Reservoir, located approximately 4 mi south of the RNGF.

The water from the Upper Warren Res rvoir travels via Bad Luck Brook to the East Branch of the Palmer River and then via the Palmer River to Shad Factory Pond. Shad Factory Pond supplies drinking water to the Bristol County Water Co. Water is drawn from Shad Factory Pond and travels by pipeline to a water treatment plant in Warren, Rhode Island. The Bristol County Water Co. is a blended drinking water system supplying approximately 50,000 customers in Rhode Island.

The soils underlying the site consist of coarse sandy, mixed, mesic Typic Dystrochrepts. These are loams of the Charlton-Paxton Series of Paxton-Whiteman-Ridgebury association. The series are deep and well drained. They have a brown, dark yellowish brown, and yellowish brown fine sandy loam B horizon and a light brownish gray, gravelly sandy loam C horizon. Charlton soils are deep and well drained and are typically uplands on slopes ranging from 0 to 35 degrees but dominantly 3-35 degrees. At the RNGF, the soils are more typically extremely stony fine sandy loams of 0-15\% slopes (USGS 1978).

\subsubsection{Groundwater and Hydrogeology}

\subsubsection{Local Geology}

The Seaboard Lowlands are comprised of a surface mantle of unconsolidated Pleistocene glacial, alluvial, and marine origin overlying a sequence of Mississippian-Permian aged metasediments. These sediments are contained within and generally reflect the northeast-southwest trending Narragansett Basin and consist of a 12,000-ft sequence of interlayered sandstones, conglomerates, shales, carbonaceous arkoses, volcanics, and meta-anthracite coal. 
The surface material is composed of two general categories of glacial material - till and stratified drift - each having different modes of origin. During the Pleistocene Epoch, moving ice scraped up soil material and abraded bedrock. This material was spread out or heaped up by the ice; or as the ice melted, the material was dropped as an unsorted, heterogenous mixture of clayey till. The remaining material was picked up by meltwater and deposited as stratified drift consisting of sorted beds of gravel, silt, and clay.

The metasediments appear to have originally evolved from series of sands, pebbles, silts, clays, and mixed debris of nonmarine fluvial origin. The deposits suggest an environment of faunal swamps associated with constantly fluctuating streams, which may have existed in a subsiding or tilting basin or graven. The occurrence of red beds and subaerial volcanics grading to coarse clastics in association with shales and coals southward indicates a southerly paleoslope in an environment of Pennsylvanian erosion and deposition. These were later metamorphosed by both the intrusion of the Narragansett Pier Granite and local Upper Paleozoic metamorphism and partial remobilization.

Figure 4 is a generalized geologic sketch map and basic stratigraphy of the Narragansett Basin describing the pre-Pennsylvanian through Pleistocene section. The map identifies the general location of various sequences, and the accompanying chart provides their description and stratigraphic position (Mosher 1976).

\subsubsection{Local Hydrogeology}

The following description of local hydrogeology is mostly from Water Resources of the Coastal Drainage Basins of Southeastern Massachusetts, Westport River. Westport to Seekonk (Willey et al. 1978). The principal surficial aquifer of the Rehoboth area is located in the north central portion of a $0.5-1.25-\mathrm{mi}$-wide, north-south elongate aquifer band extending from the Manwhague Swamp to the north to the Rhode Island border to the south. This aquifer is composed of compact unsorted silt and bouldery gravel (till). The aquifer may include small beds and lenses of poorly sorted stratified gravel, sann, and silt; and in some areas, the aquifer is mantled with relatively thin deposits of silt, sand, and gravel. This aquifer has a saturated thickness of less than $25 \mathrm{ft}$ and lies immediately above bedrock in most areas. Historically, the water levels in the glacial aquifer in the Rehoboth area can be within $4 \mathrm{ft}$ of the surface (Socolow et al. 1990). Storm-water and surface runoff discharges directly to subsurface recharge areas for the local unconfined glacial aquifer. 


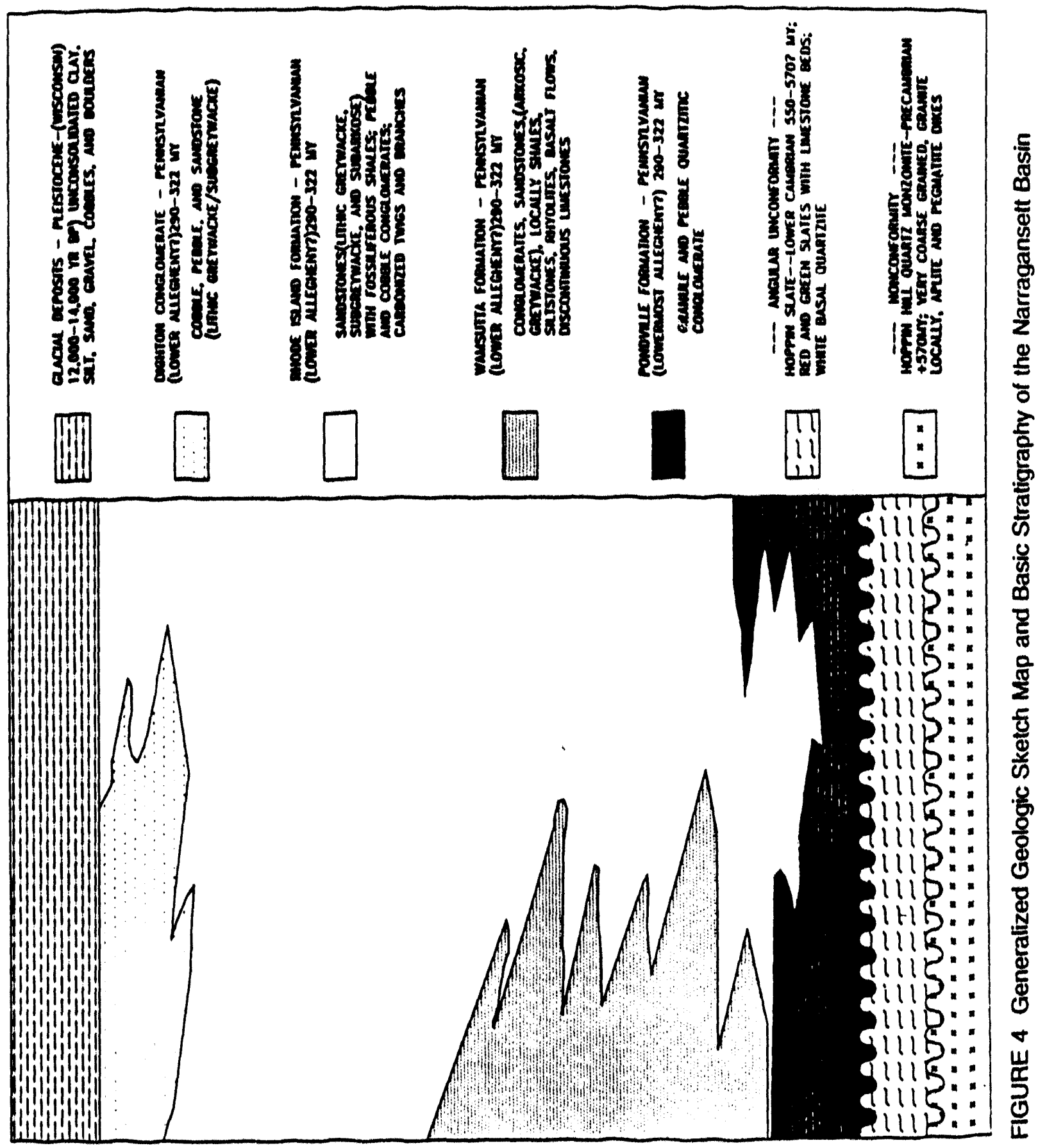


Surrounding and adjacent to the principal surficial aquifer band is a 1-2-mi-wide zone of fine to coarse and medium to coarse sand of outwash plains that are more gravelly in the west than in the east. The band grades from coarser to finer materials going southward. Transmissivity of unconsolidated deposits in this surrounding band ranges from less than $10 \mathrm{ft}^{2} / \mathrm{d}$ for till, silt, and clay to more than $26,000 \mathrm{ft}^{2} / \mathrm{d}$ in thick deposits of sand and gravel.

A secondary aquifer occurs from 25 to $140 \mathrm{ft}$ below land surface. This aquifer consists of the secondary pore spaces, such as joints and fractures, and the more permeable layers in the Pennsylvanian clastic sedimentary rocks. Because of varying differences in composition and metamorphism, hydrologic conditions are variable in these formations and do not reflect a consistent regional pattern of variation. Reported yields from wells in these rocks range from $8 \mathrm{gal} / \mathrm{min}$ to $170 \mathrm{gal} / \mathrm{min}$, with a median yield of $8 \mathrm{gal} / \mathrm{min}$. The town of Rehoboth requires private drinking water wells be drilled to the depth of 300-425 $\mathrm{ft}$ and sealed at the beginning of the bedrock to ensure that water is drawn from this secondary aquifer located in bedrock joints and fractures.

\subsubsection{Local Groundwater Usage}

Local communities within a 4-mi radius of the RNGF include Rehoboth, Attleboro, Norton, Taunton, and Dighton, Massachusetts. Each community was contacted to determine the source of its population's water supply. The municipal drinking water sources are shown on Figure 5.

In Rehoboth, all residents are required to draw their drinking water from private wells. These wells are typically 325-400 ft deep (Currey 1993). Wells are not required to be registered, and older wells that draw from the surficial aquifer may exist. Approximately 3,500 homes have private wells in Rehoboth.

All residents in Attleboro are served by municipal water service. The ten municipal wells that serve the Attleboro Water Department are located outside a 4-mi radiur of the RNGF. No known private drinking water wells are located in Attleboro.

The five municipal wells that serve the Norton Water Department are located outside a 4-mi radius of the RNGF. All residents of Norton are served by municipal water service. No known private drinking water wells are located in Norton. 


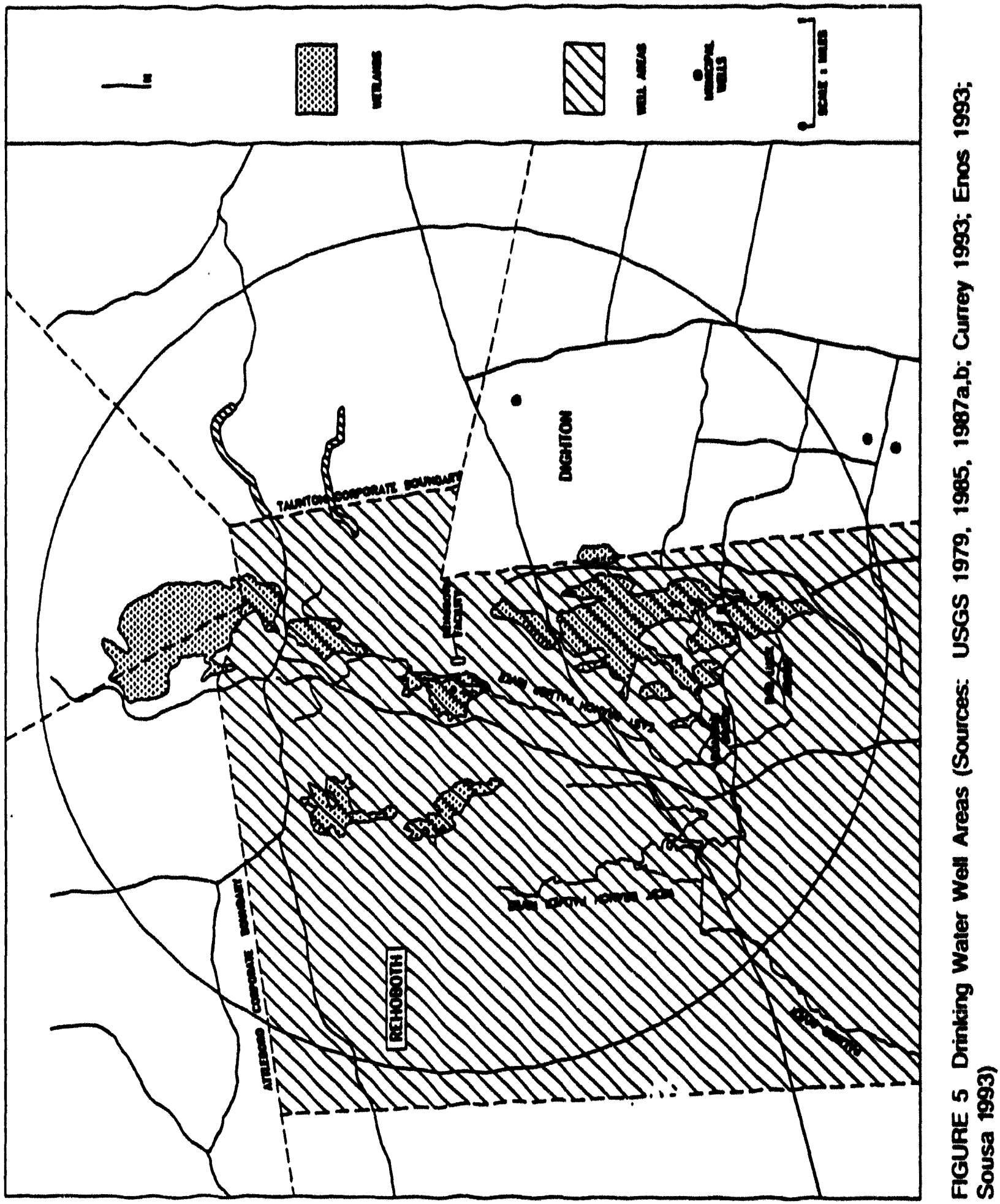


Taunton obtains all of its municipal dirinking water from surface water sources. These two sources, Elders Pond and Assawompset Pond, are located in Lakeville, Massachusetts, more than $10 \mathrm{mi}$ from the RNGF. The Board of Health in Taunton knows of some wells on Glebe Street and Tremont Street in the westernmost part of Taunton. The municipal water service ends at Burt Streel, and houses to the west of that line are served by private drinking water wells. Although new wells are required to be registered and drilled to deeper than $70 \mathrm{ft}$, Board of Health personnel. indicated that the old wells, which are not required to register in Taunton, are historically less than $30 \mathrm{ft}$ deep and are located in the sand and gravel of the surficial aquifer (Enos 1993).

In Dighton, the population is served by municipal drinking water (Sousa 1993). Five of the six municipal water wells lie within a 4-mi radius of the RNGF. These wells include the Walker Street wells and the Cedar Street wells. These wells are approximately $35 \mathrm{ft}$ deep and gravel packed. North Dighton, which lies just $4 \mathrm{mi}$ from the RNGF, obtains its drinking water from the Taunton Water Department (Sousa 1993). Private wells are not required to be registered in Dighton; therefore, determining if any private drinking water wells exist was not possible.

The RNGF obtains its drinking water from an on-site well. No well logs are available for the site, nor were they available at the local government office (USAEHA 1987). The Potable Water System Survey (USAEHA 1987) concluded that the drinking water at the RNGF was fit for human consumption and was not expected to cause either short-term or long-term adverse health effects, even though the water did not meet the National Secondary Drinking Water Regulations (NSDWR) for $\mathrm{pH}$, corrosivity, and manganese at the wellhead and sometimes also exceeded the NSDWR standard for iron at the tap.

The Potable Water System Survey (USAEHA 1987) included a complete scan for organics in the water from the on-site wells. Organics were of particular concern at Rehoboth because activities at old Nike sites in some areas of the country have contaminated groundwater with various solvents used for cleaning equipment. The data of this study show elevated levels of 1,1,1-trichloroethane in certain samples, although all levels are below the EPA's maximum contaminant level (MCL). The study states that these levels were laboratory error because of the random appearance of 1,1,1-trichloroethane in other samples taken during the same week. Therefore, the study concludes that no organic contamination exists at Rehoboth, indicating that the past activities at the Nike site had not contributed any contaminants to the water supply. 


\subsubsection{Sensitive Environments}

Wetlands surround the RNGF on three sides. The East Branch of the Palmer River runs approximately one-quarter of a mile from the RNGF. The East Branch runs south of the site for approximately 3 mi to where it joins the West Branch to form the Palmer River. The Palmer River runs south to where it enters Narragansett Bay.

Immediately adjacent to the RNGF to the west lies a 13-acre portion of the Rehoboth State Forest that lies between the site and the East Branch of the Palmer River. Another portion of the Rehoboth State Forest (approximately 123 acres) lies $1 / 4 \mathrm{mi}$ to the north of the site. Figure 3 shows the location of these areas. The Rehoboth State Forest is an unimproved forest area. No water wells, trails, or other facilities exist. Both areas of the forest are mostly upland, with mixed oak, white pine, beech, and black birch. Some cedar swamp and red maples are found in the more poorly drained lower areas near the East Branch. The East Branch is designated class B by the Miassachusetts Department of Environmental Quality, and water quality must be maintained as a habitat for fish, other aquatic life, and wildlife and for primary- and secondary-contact recreation. Although the East Branch is not stc sked, it may contain indigenous fish, including pickerel, small bass, sunfish, and perch (Mason 1993), and the public may fish these areas.

In Massachusetts, the 0.5 -mi radius surrounding any municipal drinking water supply well is designated a wellhead protection area (310 CMR 22.02 and 22.21; Division of Water Supply's "Guidelines and Policies for Public Water Systems," as amended). Therefore, the 0.5-mi-radii surrounding the municipal drinking water wells located in Dighton are wellhead protection areas that lie within a 4-mi radius of the RNGF. 


\section{Environmentally Significant Operations}

The PA team from Argonne identified three ESOs at the RNGF: (1) the vehicle fuel dispensing station, vehicle operator maintenance, and the vehicle washracks, (2) filling underground heating oil tanks, and (3) abandoned underground storage tanks and wells. Figure 6 shows the locations of the ESOs.

\subsection{Vehicle Fuel Dispensing Station, Vehicle Operator Maintenance, and Vehicle Washracks}

The dispensing of fuel at the vehicle fuel dispensing station creates the potential of a release of fuels to the environment. The assumption can be made that dispensing has always been from this dispensing station; however, no record or information of past releases of fuel exists. Currently, a containment area of plastic sheeting and sandbags has been constructed to prevent the release of small to medium spills of fuel to the surrounding asphalt during refueling operations. Larger spills, however, would run off to the surrounding soils to the northeast of the parking area or possibly to the vehicle washracks and thereby to the storm-water outfall.

The diesel fuel supplying the fuel dispensing station is stored in an underground storage tank installed in November 1987. The tank was tested for integrity (regarding releases to the environment) upon installation and again in 1991 and conforms to current Massachusetts regulations.

The vehicle washracks are used only to hose off vehicles returning from drills. Currently, no detergents or soaps are to be used; however, no information exists concerning past usage of the washrack oil/water separators. If properly maintained, oil/water separators in the washracks prevent the discharge to the environment of oily waters coming off of the vehicles.

The vehicle operator maintenance currently taking place at the RNGF does not create a potential for a release to the environment. No information was available concerning past vehicle maintenance practices; however, the RNGF holds a Massachusetts small-quantity waste-generator identification number because of past generation of vehicle maintenance wastes. 


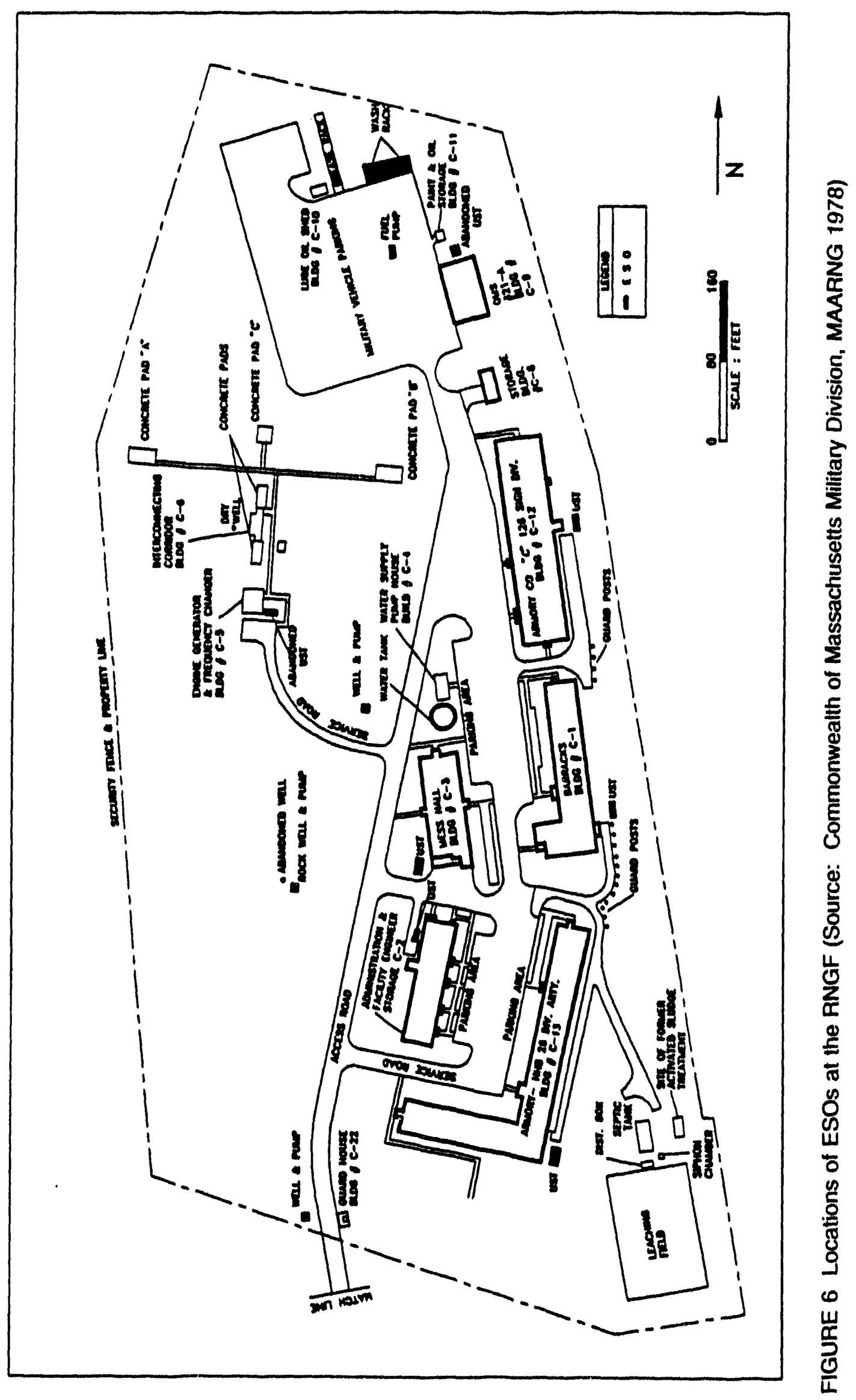




\subsection{Filling Underground Heating Oll Tanks}

Five active heating fuel oil tanks are located at the RNGF. The tanks the nselves are not ESOs; however, spillage of fuel oil was noted in the gravel and dirt surrounding the fill pipes for all of the tanks. These stains imply a current and historical practice of spillage during the filling of these tanks. Visible signs of spillage measure approximately $2 \mathrm{ft} \times 3 \mathrm{ft}$ around the fill pipe for the fuel tank serving Building C-13. Spills would run off down the hill to a storm-water diversion swale. Signs of spillage around the fill pipe for the fuel tank serving Building $\mathrm{C}-1$ measure about $2 \mathrm{ft} \times 3 \mathrm{ft}$, and spills would run down the hill to grassy soil. The fill pipe for Building C-12 was covered with a rusty coffee can, and visible signs of spillage measure approximately $2 \mathrm{ft} \times 3 \mathrm{ft}$. Spills would run off down the hill to grassy soil. The fill pipe serving the underground storage tank servicing Building C-3 is located within the storm-water drainage ditch. No visible signs of spillage are present, probably due to storm-water wash. The fill pipe for the underground storage tank serving Building $\mathrm{C}-2$ has visible signs of spillage measuring approximately $2 \mathrm{ft} \times 3 \mathrm{ft}$ in the soil. Spillage would run off into the storm-water drainage ditch. The storm-water drainage system from this area flows via ditches to the access road and then south to Fairview Avenue or via a rock blanket gutter to the east to Francis Street.

\subsection{Abandoned Underground Storage Tanks and Wells}

To the north of Building C-9 is a standpipe flush with the ground level. The pipe contains an uncharacterized liquid. This standpipe suggests the presence of an abandoned underground storage tank. In addition, to the east of the generator building (Building C-5) is another large underground storage tank with a fill pipe and vent pipe above ground level. This tank is reflected on site plan drawings as a 2,000-gal fuel oil storage tank. This tank contains product, although it has not been used in some years.

To the west of well No. 2 is a plate approximately 6 in. in diameter lying flush to the ground. The plate has been welded in place; however, it is not completely closed. A coin dropped into the hole indicated that the hole is very deep and has liquid at the bottom. Possibly this hole is an abandoned water well that has not been properly closed. 
To the west of the interconnecting corridor building (Building C-6) is an abandoned dry well. Because dry wells or sumps at Nike sites were sometimes used for the disposal of wastes, including oils and solvents (McMaster et al. 1984), this well should be investigated for contamination. 


\section{Known and Suspected Releases}

\subsection{Releases to Groundwater}

No releases of contaminants to groundwater are known. The Potable Water System Survey (USAEHA 1987) included a complete scan for organics in the water from the on-site wells. Organics were of particular concern at Rehoboth because activities at old Nike sites in some areas of the country have contaminated groundwater with various solvents used for cleaning equipment. The data of this study show elevated levels of 1,1,1-trichloroethane in certain samples. although all levels are below the EPA's MCL. The survey concludes that these levels were laboratory error and that no organic contamination exists at Rehoboth, indicating that the past activities at the Nike site had not contributed any contaminants to the water supply (USAEHA 1987).

\subsection{Releases to Surface Water}

No releases of contaminants to surface water are known. The only.potential releases of contaminants to surface water are from storm-water runoff from the military vehicle parking area, particularly if there is a spill at the diesel fuel dispensing island; storm-water runoff from the areas of visible fuel oil spills from refilling the underground storage tanks; and the discharge from the vehicle washracks, which should contain no contaminants (in that the racks have oil/water separators and policy dictates that no detergents be used), except in the case of a large diesel fuel spill that may migrate to the washracks and overwhelm the oil/water separators.

\subsection{Releases to Soll}

On January 4, 1988, while plowing the access road from the parking area to the armory (Building C-13), the plow operator noticed that the spigot on the gas truck being used to plow was open, and approximately $245 \mathrm{gal}$ of fuel was lost along the road. Through the assistance of emergency response personnel from Camp Edward, every effort possible was made to clean the area of any excess fuel. The incident report indicates that the fuel pooled in a low spot in the parking lot. Sand was spread to absorb excess fuel. The sand was then picked up and disposed of in plastic barrels. Notice was given to the Massachusetts Department of Environmental Quality, the Lakeville Hospital, and the Rehoboth Fire Department. The spill residues were disposed of as 
hazardous waste through a regulated contractor. No current signs of the spill were found, and no distressed vegetation or absence of animal life was seen. No adverse off-site environmental effects were associated with this release.

Spillage of fuel oil is noted in the gravel and dirt surrounding the fill pipes for all of the five active heating fuel oil tanks located at the RNGF. These soil stains average $2 \mathrm{ft} \times 3 \mathrm{ft}$.

\subsection{Releases to Alr}

No releases of contaminants to the air are known.

\subsection{Other Releases}

No other significant releases of contaminants to the environment have been identified for the RNGF. 


\section{Human and Environmental Receptors}

\subsection{Groundwater}

The groundwater system around the RNGF consists of a principal surficial aquifer composed of compact unsorted silt and bouldery gravel and a secondary aquifer located in deeper bedrock fractures and joints. Insufficient information exists to determine (1) the exact location of these aquifers, (2) if there are other surrounding aquifers, or (3) the directional flow of the groundwater underlying the RNGF; therefore, accurately predicting the migration pathway for potential groundwater contamination from the RNGF is not possible. Generally, the greatest potential for migration of contaminants is laterally through the surficial aquifer, with limited vertical migration to the bedrock aquifer.

Insufficient information exists to conclude that the municipal water wells in Dighton or any other private water wells draw from the same surficial aquifer underlying the RNGF; however, if they did, the sand-and-gravel surficial aquifer would be a potential migratory pathway. The town of Rehoboth requires that all newer wells be $300-425 \mathrm{ft}$ deep to draw from the bedrock aquifer and that such wells be sealed to prevent drawing from the surficial aquifer. Such sealing would also prevent migration from the surficial aquifer to the bedrock aquifer via these deep wells. Therefore, potential migration of contaminants from the RNGF to private water wells in Rehoboth would be via joints and fractures in the bedrock.

\subsection{Surface Water}

Surface water contamination would flow west from the RNGF to the East Branch of the Palmer River and the Great Meadows Swamp to the Palmer River. The Palmer River runs south to Shad Factory Pond and onward to Narragansett Bay. Contamination would flow east to the access road and Fairview Avenue and Francis Street. The runoff would flow along these streets south to Squannakonk Swamp and, eventually, to Bad Luck Swamp to the south. Bad Luck Swamp forms the watershed for the Upper Warren (Anawan) Reservoir, located approximately $4 \mathrm{mi}$ south of the RNGF. Water from the Upper Warren Reservoir travels along Bad Luck Brook to the Palmer River and on to Shad Factory Pond and eventually to Narragunsett Bay. 
Shad Factory Pond supplies drinking water to the Bristol County Water Co. Water is drawn from Shad Factory Pond and travels from there via pipeline to a water treatment plant in Warren, Rhode Island. The Bristol County Water Co. is a blended drinking water system supplying approximately 50,000 customers in Rhode Island.

In addition, although the East Branch of the Palmer River is not stocked, it may contain indigenous fish, including pickerel, small bass, sunfish, and perch (Mason 1993), and the public may fish these areas.

\subsection{Soll}

Soil contamination was documented at the RNGF around the fill pipes for the five active underground fuel oil tanks. These soil stains average $2 \mathrm{ft} \times 3 \mathrm{ft}$. The fuel spill of 1988 was reme diated. The prevailing winds are northwesterly in the winter months and southwesterly in the summer months, with an annual mean speed of $10.6 \mathrm{mi} / \mathrm{h}$. Therefore, dispersal of contaminated soil would travel toward residences along Francis Street and the northern portion of Rehoboth State Forest during the summer months and toward the Great Meadow Marshes during the winter months.

\subsection{Alr}

No releases to the air are known. As stated previously, southwesterly winds would affect residences in Dighton and the Great Meadow Marshes, and the northwesterly winds would affect residences along Francis Street and the northern portion of Rehoboth State Forest. Given the limited sources for airborne contumination, no off-base receptors have been identified.

\subsection{Other Receptors}

No other rec $\because$.ors of contaminants from the RNGF have been identified. 


\section{Proliminary Assessment Findings and Conclusions}

\subsection{Summary of Preliminary Assessment Findings}

The RNGF is a 15-acre site located in the southeastern portion of Massachusetts, approximately 3 mi northeast of Rehoboth, Massachusetts, in Bristol County. The primary ESOs are (1) a vehicle fuel dispensing station, vehicle operator maintenance (i.e., adding oil or other fluids, checking batteries and fluid levels, etc.), and the vehicle washracks; (2) filling underground heating oil tanks: and (3) ahundoned underground storage tanks and wells.

\subsection{Recommendations for Further Action}

The primary objective of the PA is to identify and evaluate ESOs that would result in either (1) immediate action, (2) site investigation, or (3) no further PA/IRP action. Generally, the available information indicates that the RNGF presents a low level of threat to human health and the environment: however, on the basis of the information made available to Argonne, the following areas deserve further consideration to ensure protection for the locul community and the environment. Although not necessarily waste sources under the IRP guidelines, Argonne's reviewers noted the following areas of concem, which could result in the releuse of contaminunts to the environment:

- On the west side of the leach field, two to three garbage cans have been burned to ash on the soil, leaving a gummy, white-silver ash (possibly film destruction) that will leach into the soil.

- Although the abandoned sewage treatment plant has been removed, no sampling of the soil was done after removal and before refilling and grading, so whether any contamination is present at this location is unknown.

- A small cap, which is located about $8 \mathrm{ft}$ from the current pump and well. covers a very deep hole that contains liquid, possibly an old abandoned well that has not been closed completely. 
- An abandoned 2,000-gal fuel oil underground storage tank, still containing product, is located next to the generator building (Building C-5) on the hill.

- All five active underground storage tanks containing heating oil have stained areas around the fill pipes. Some pipes are situated to allow any spillage to run off into the storm-water collection system, but in other cases, runoff is into the soil.

- A small 1-in.-diameter pipe runs out of the wall behind Building C.9; the pipe is very rusted, and its origin could not be ascertained because no one had a key for the building.

- The temporarily capped standpipe of another abandoned underground storage tank, containing an unknown liquid, was located to the north of Building C.9.

- Stains are visible on the diesel fuel dispensing island; a makeshift spill containment consists of plastic sheeting and sandbags.

- Located west of the interconnecting building (Building C-6) is a dry well, which may have been used for disposal of wastes during the years when the sile was a Nike battery control area.

To prevent any releases to the sensitive environments surrounding the RNGF, the following actions are recommended:

- Soil samples should be taken on the west side of the leach field. where two to three garbage cans have been burned, to determine that the residue is not hazardous and has not leached into the soil.

- Document that no contamination of the soil exists at the previous location of the sewage treatment plant.

- Investigate the hole near well No. 2 ; if it is an abandoned well, properly close the well under Massachusetts well regulations. 
- Investigate and remove any abandoned underground storage tanks, including one next to Building C.9 and one next to Building C.5.

- Investigate the small 1 -in.-diameter pipe that runs out of the wall behind Building C-9 for possible battery-acid treatment contamination of the outside soil at the outfall.

- Investigate the dry well located west of Building C-6 to determine if the dry well was used for waste disposal. 


\section{Sources of Information}

\subsection{References}

Bair, F.E., 1992, Weather of U.S. Cities, 4th ed., Gale Research Inc., Detroit, Mich.

Commonwealth of Massachusetts Military Division, MAARNG, 1978, "Sewer, Storm Drain, Water Service," drawing No. 255-78-0000 (blueprint), Sept. 22 (limited distribution).

Currey, R., 1993, personal communication. Bourd of Health, Rehoboth. Mass.

Enos, E., 1993, personal communication, Taunton Board of Health. Taunton, Mass.

EPA: See U.S. Environmental Protection Agency.

Harrison, W., et al., 1983, Geology, Hydrology and Mineral Resources of Crystalline Rock Arcas of the Northeastern United States, ANL/ES-136, part 1, Argonne National Laboratory, Argonne. III.

Law Engineering Testing Co., 1986, Final Report: Investigation of Former Nike Missile Sites for Potential Toxic and Hazardous Waste Contamination, vol. 1, prepared by Law Engineering Testing Co., LES-Government Services Division, Atlanta, Ga., for the Department of the Army. Huntsville Division, Corps of Engineers, Huntsville, Ala., March (limited distribution).

Mason, A., 1993, personal communication, Myles Standish State Forest (Rehoboth State Forest), Carver, Mass.

McMaster, B.N., et al., 1984, Historical Overview of the Nike Missile System, prepared by Environmental Science and Engineering, Inc., Gainesville, Fla., for Army Toxic and Hazardous Materials Agency, Assessment Division, Aberdeen Proving Ground, Md., Dec, (limited distribution). 
Mosher, 1976, Geology of Southeastern New England: A Guidebook for Field Trips to the Boston Area and Vicinity, 68th Annual Meeting, NEIGC, B. Cameron (editor), Science Press, Princeton, N.J.

Ruffner, J.A. (editor), 1985, Climates of the States, National Oceanic and Atmospheric Administration, Narrative Summaries, Tables and Maps for Each State with Overview of State Climatologist Programs, 3rd ed., Gale Research Inc., Detroit, Mich.

Socolow, R.S., et al., 1990, Water Resources Data: Massachusetts and Rhode Island Water Year 1990. USGS Water Data Report MA-RI-90-1, U.S. Geological Survey, Boston, Mass.

Sousa, R., 1993, personal communication, Dighton Water Department, Dighton, Mass.

USAEHA: See U.S. Army Environmental Hygiene Agency.

U.S. Army Environmental Hygiene Agency, 1987, Potable Water System Survey, Massachusetts Army National Guard, Wayland and Rehoboth, Massachusetts, 6-10 April, 1987, Water Quality Engineering Study No. 31-24-0774, Aberdeen Proving Ground, Md. (limited distribution).

U.S. Environmental Protection Agency, 1991, Guidance for Performing Preliminary Assessments under CERCLA, publication 9345.0-01A, Office of Emergency and Remedial Response, Office of Solid Waste and Emergency Response, Washington, D.C.

USGS: See U.S. Geological Survey.

U.S. Geological Survey, 1978, "General Soil Map, Bristol County, Massachusetts, Northern Part," Denver, Colo.

U.S. Geological Survey, 1979, "East Providence Quadrangle, Massachusetts, Bristol Co.," USGS map, 7.5-Minute Series (topographic), photo revised, Denver, Colo.

U.S. Geological Survey, 1985, "Somerset Quadrangle, Massachusetts, Bristol Co.," USGS map, 7.5-Minute Series (topographic), Denver, Colo. 
U.S. Geological Survey, 1987a, "Taunton Quadrangle, Massachusetts, Bristol Co.," USGS map, 7.5-Minute Series (topographic), Denver, Colo.

U.S. Geological Survey, 1987b, "Attleboro Quadrangle, Massachusetts, Bristol Co.," USGS map, 7.5-Minute Series (topographic), Denver, Colo.

Willey, R.E., et al., 1978, "Water Resources of the Coastal Drainage Basins of Southeastern Massachusetts, Westport River, Westport to Seekook," in USGS Hydrologic Investigations Atlas, HA-275, U.S. Geological Survey, Denver, Colo.

\subsection{Other Sources}

Monroe, M., 1993, personal communication, Bristol County Water Co., Bristol, R.I.

USGS: See U.S. Geological Survey.

U.S. Geological Survey, 1991, Public Water-Supply in Massachusetts, 1986, open-file report 91-86, prepared in cooperation with the Massachusetts Department of Environmental Management, Office of Water Resources, Boston, Mass. 
Appendix:

Interview Information 


\section{Appendix:}

\section{Interview Information}

\section{Individuels Interviewed}

State Environmental Manager

MAARNG Headquarters

Camp Curtis Guild

25 Haverhill Street

Reading, Massachusetts

(617) $944-0500 \times 2525$

Environment Project Manager

MAARNG Headquarters

Camp Curtis Guild

25 Haverhill Street

Reading, Massachusetts

(617) $944-0500 \times 2520$

Motor Sergeant

RNGF

Rehoboth, Massachusetts

(508) 672-8529

Health Agent

Board of Health

148 Peck Street

Rehoboth, Massachusetts

(508) 252-3099

Town Clerk of Attleboro

77 Park Street

Attleboro, MA 02708

(508) 223-2222 x 3131
Forester

Myles Standish State Forest

Box 66

Carver, Massuchusetts 02566

(508) 866-2580

Superintendent

Bristol County Water Co.

49 Bradford Street

Bristol, Rhode Island

(401) 245-9230

Superintendent

Dighton Water Department

Dighton, Massachusetts

(508) 822-5461

Town Clerk of Norton

70 E. Main Street

Norton, MA 02766

(508) 285-0230

Superintendent

Norton Water Department

70 E. Main Street

Norton, MA 02766

(508) 285-0282

Board of Health

Taunton, Massachusetts

(508) $821-1400$ 


\section{Argonne Investlgators}

Rebecca A. Haffenden

(708) 252.5159

Sam Flaim

(303) $986-1140 \times 244$

Michael Krokosz

(708) 252-5027 

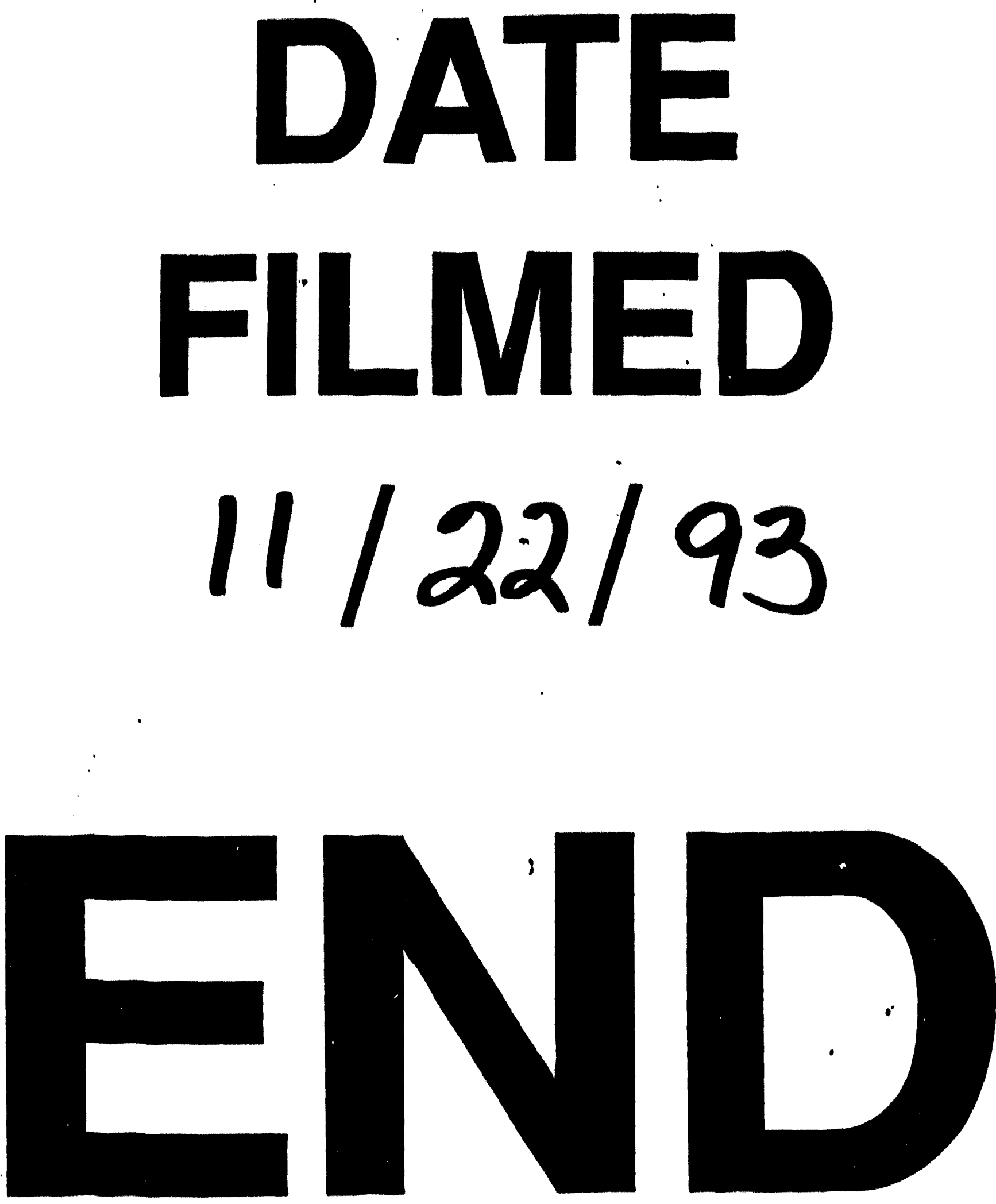


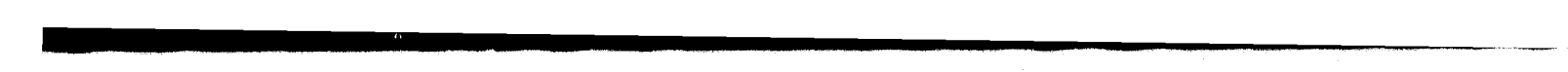

